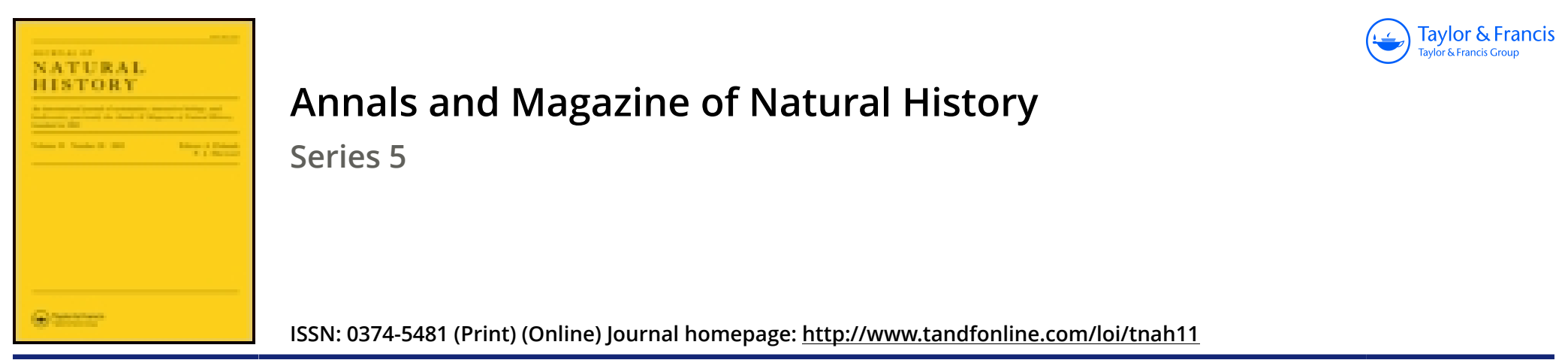

\title{
On parthenogenesis in bees
}

\section{M.A. Sanson}

To cite this article: M.A. Sanson (1878) On parthenogenesis in bees, Annals and Magazine of Natural History, 2:12, 497-498, DOI: 10.1080/00222937808682468

To link to this article: http://dx.doi.org/10.1080/00222937808682468

$$
\text { 曲 Published online: } 15 \text { Oct } 2009 .
$$

Submit your article to this journal

LIIl Article views: 4

Q View related articles $\asymp$ 
two candals are nearly round, especially the penultimate, the diameter of which is 65 millims.

The ribs of the first pair have their sternal extremity much more widened than in $B$. biscayensis.

The scapula is a little thicker than in the latter species, and presents a very small rudiment of the coracoid apophysis. It is much wider than high; as in the B. biscayensis of Naples and Philadelphia, its width is 15 centims. more than its height.-Comptes Rendus, September 9, 1878, p. 410.

\section{On Parthenogenesis in Bees. By M. A. Sanson.}

In a recent note* M. J. Perez throws doubt upon the phenomenon of parthenogenesis in bees, taking his stand upon a certain interpretation of facts of heredity which he has observed. I am surprised to find him speaking of a fact as hypothetical which has been demonstrated experimentally a great many times, and the verification of which is a very easy matter. In 1868 (Comptes Rendus, tom. Ixvii. p. 51) the Academy had before it a proof of this fact. I exhibited a comb containing only worker-cells filled with males or drones developed in those cells. M. Bastian and myself had obtained it at Wissembourg, by causing a female, the seminal receptacle of which was destitute of spermatozoids, to deposit her eggs in it. I also, at the same time, exhibited workers lodged in drone-cells, and produced from eggs laid by a fecundated female which had no other cells at her disposal. The purpose of our experiments had been to check the theory put forward by Landois with regard to the mode of development of the sexes. All beekeepers who are au courant of science know that the old queens which become drone-mothers (bourdonneuses) - that is to say, which no longer lay any but drone-eggs-have exhausted their provision of spermatozoids. When their seminal receptacle is examined under the microscope, it contains only a perfectly transparent fluid. We know also that lowering the temperature of a young fecundated queen to such a degree as to kill the spermatozoids suffices to render her inmediately a drone-mother. The joung queens which have never coupled, and the workers which sometimes lay in hives which, having lost their queen by accident, are called orphan-hives, only deposit male eggs.

'These are facts acquired for science. It is easy to show, moreover, that the interpretation of his observations given by $\mathbf{M}$. Perez is not the correct one. In a hive, the queen of which, he says, was the daughter of an Italian of pure race and had been fecundated by a French male, he examined with scrupulous care 300 drones. He found the Italian characters in 151, those of hybrids of different degrees in 66, and the French characters in 83, "from which," he adds, "it evidently follows that the eggs of drones, like the eggs of females, receive the contact of the semen deposited by

* See Ann. \& Mag. Nat. Hist. November, 1878, p. 428.

Ann. \&. Mag. N. Hist. Ser. 5. Vol. ii. 
the male in the organs of the queen, and that Dzierzon's theory, created to explain an ill-ascertained fact, becomes useless if this fact is disproved."

One is by no means struck with the evidence of any such conclusion, being in a position to adduce the intervention of the known laws of heredity. With an Italian queen of incontestably pure race the drones have exclusively the Italian characters, although she may have coupled with a male of a different race. The workers alone are bybrids. The author has evidently had before him a case of reversion. He had in his hive, as he tells us, true Italian workers, others French, and others, again, presenting a mixture in diverse proportions of the characters of the two races. This is in coniormity with the usual results of crossing. The queen of this hive was no doubt an Italian of the same sort as the workers of his first category. The atavism of a black male which intervened in a preceding generation has manifested itself in different degrees. The same fact is often presented in German and French hives into which Italian queens have been introduced. I remember having myself made a similar observation in the hive of M. Bastian at Wissembourg, ascertaining the hybrid origin of the queen, the external characters, however, of which were purely Italian.

At any rate, it is not in conformity with the present condition of scienco to represent the parthenogenesis of bees as a hypothesis accepted solely becauso of its utility in explaining a fact which is incontestable; for its reality bas long since been established by experiment._Compies Rendus, October 28, 1878, p. 659.

\section{The Development of Ligula. By M. Duchamp.}

On the 24th December last M. Duchamp presented a note to the Academy of Sciences, in which he showed, by experiments made on the common pigeon, that for the development of Ligula monogramma, Crepl., into a perfect Cestoid it is not necessary that the worm should be introduced into the body of any particular species of animal, but that it can be effected in the digestive canal of any warm-blooded vertebrate.

Continuing his investigations, M. Duchamp endeavoured to rear the Ligulce in artificial media, such as meat-soup, \&c., kept at a temperature of about $38^{\circ} \mathrm{C}$. $\left(100^{\circ} \mathrm{F}\right.$ ), but without success. He then introduced a certain number of Ligula, derived from two tench, into the peritoneal cavity of a dog. No symptoms of peritonitis were produced; and the dog having been killed four days after the operation, the Ligulce were found living with their reproductive organs developed and in full functional activity, the testes being inflated with spermatic cells, and the ova already formed. One of the Ligulae thus transported from the tench to the dog had been divided into two parts; and each fragment was developed in the same way as the entire individuals.-Ann. des Sci. Nat., Zool. sér. 6 , tome vii., August 1878 . 